\title{
Collecting verse: "significant shape" and the paper-book in the early seventeenth century
}

Article

Accepted Version

O'Callaghan, M. (2017) Collecting verse: "significant shape" and the paper-book in the early seventeenth century.

Huntington Library Quarterly, 80 (2). pp. 309-324. ISSN 1544399X doi: https://doi.org/10.1353/hlq.2017.0018 Available at https://centaur.reading.ac.uk/66752/

It is advisable to refer to the publisher's version if you intend to cite from the work. See Guidance on citing.

Published version at: https://muse.jhu.edu/journal/677

To link to this article DOI: http://dx.doi.org/10.1353/hlq.2017.0018

Publisher: University of Pennsylvania Press

All outputs in CentAUR are protected by Intellectual Property Rights law, including copyright law. Copyright and IPR is retained by the creators or other copyright holders. Terms and conditions for use of this material are defined in the End User Agreement.

www.reading.ac.uk/centaur

\section{CentAUR}


Central Archive at the University of Reading

Reading's research outputs online 
Collecting verse: "significant shape" and the paper-book in the early seventeenth century

Michelle O’Callaghan

Abstract: This essay investigates practices of manuscript compilation, taking Bodleian Library Don.c.54 and Bodleian Rawl.poet.31 as its main case studies. Both manuscripts evidence a degree of organization and planning, and thus possess a "significant shape", despite the one (Rawl.poet.31) having been produced by a professional scribe in a short space of time as a commercial enterprise, whilst the other (Don.c.54) was compiled by its owner (an amateur scribe), over the course of three decades. As such, the essay uncovers the high level of skill, and awareness of manuscript design, that amateur as well as professional copyists could display, and explores the kinds of interpretive work required to analyze the complex interrelationship between material form and textual content.

A notable feature of recent studies of manuscript miscellanies has been the critical interest in how miscellanies were compiled. ${ }^{1}$ Verse miscellanies pose particular challenges in this respect because the manuscripts this category encompasses vary considerably in terms of their methods of compilation and physical format, from prebound, blank paper-books to sammelbände, composite manuscript books often made up of small booklets and loose papers, written on different paper sizes and stocks. ${ }^{2}$ To bring some order to this heterogeneity, a distinction is sometimes drawn between the "miscellany" and "anthology" on the basis of methods of compilation. "Miscellany" is reserved for those compilations in which there is very little or no

\footnotetext{
${ }^{1}$ See, for example, Jonathan Gibson's essays, "Casting Off Blanks: Hidden Structures in Early Modern Paper Books" in Material Readings of Early Modern Culture: Texts and Social Practices, 1580-1730, ed. James Daybell and Peter Hinds (Basingstoke, 2010), 20828, and "Synchrony and Process: Editing Manuscript Miscellanies", SEL 52 (2012): 85-110; and Marcy North, "Amateur Compilers, Scribal Labour, and the Contents of Early Poetic Miscellanies”, English Manuscript Studies, 1100-1700 16 (2012): 82-111.

${ }^{2}$ North "Amateur Compilers", 82. Peter Beal defines the manuscript verse miscellany as "a compilation of predominantly verse texts, or extracts from verse texts, by different authors and usually gleaned from different sources", A Dictionary of English Manuscript Terminology, 1450-200o (Oxford, 2008), 429. See also: Henry Woudhuysen, Sir Philip Sidney and the Circulation of Manuscripts, 1558-1640 (Oxford, 2000), 163-73; Joshua Eckhardt, Manuscript Verse Collectors and the Politics of Anti-Courtly Love Poetry (Oxford, 2009), 15-21; Mark Bland, A Guide to Early Printed Books and Manuscripts (Oxford, 2010), 72-3.
} 
evidence of planning, instead the sequence of copying appears to result from happenstance, in other words, as texts come to the copyist. By contrast, "anthology" describes those compilations in which there is evidence that texts have been consciously selected, with "various schemes or guiding principles" in mind.3 While these distinctions are very valuable, they are not without difficulties; as Julia Boffey notes, there will always be grey areas where the "distinction between the planned and the chance copying” is very difficult to determine with any certainty. 4 I begin with these critical efforts to distinguish between a miscellany and an anthology not in order to put in place a rigid system of classification, but because this work brings the question of how to identify and describe practices of copying and compilation into sharp and necessary focus. In this essay, my interest is in those manuscript books that show evidence of planning and craft, which not only draws attention to the physical and intellectual work of making a collection, but, in doing so, sheds important light on the technologies of making books within manuscript cultures and the agency of copyists and compilers. 5

My principle case studies are two manuscripts, Bodleian Library Don.c.54, compiled by its owner, Richard Roberts, over three decades, and Bodleian Rawl.poet.31, an anthology produced in a professional scriptorium. Although one is an amateur and the other a professional production, both are marked by a high level of organization and skill and, because of this, can be said to possess a "significant shape". Harold Love used this phrase to describe how the presence of "linked groups' of poems", often shared with other miscellanies, provides a compilation with a discernible, if flexible structure. ${ }^{6}$ Here, Love was primarily concerned with how the content of the miscellany - groupings of verse - provides evidence for patterns of compilation. This essay will use the notion of "significant shape" to describe the points where the physical structures of the manuscript and its content productively coincide. Bodleian

\footnotetext{
3 Julia Boffey, Manuscripts of English Courtly Love Lyrics in the Later Middle Ages (Woodbridge, 1985), 11; see also Theo Stemmler, "Miscellany or Anthology? The Structure of Medieval Manuscripts: MS. Harley 2253, for Example", Zeitschrift für Anglistik und Amerikanistik 39 (1991): 231-37.

4 Boffey, Manuscripts, 7.

5 See also Jonathan Gibson's recent call for hypothetical histories of particular manuscripts that focus on the "complex interplay between physical form and intellectual structures in early modern manuscript culture", "Casting Off Blanks", 222

${ }^{6}$ Harold Love, "Scribal Texts and Literary Communities: The Rochester Circle and Osborn b. 105”, Studies in Bibliography 42 (1989): 219-34 (220-23).
} 
Don.c.54 and Rawl.poet.31 are of particular interest in this respect because they have in common an underlying structure supplied by the physical format of the commercially-produced paper-book. Paper-books were either bought pre-bound from a stationer or bookseller or bound by the compiler. In these cases, as Mark Bland notes, the underlying "integrity" of the book, with its "regular structure", is "established at the outset". 7 The material forms of the paper-book arguably therefore influence how textual material is copied into the volume and contribute to its "significant shape". In Richard Roberts's manuscript (Bodleian Don.c.54), in particular, an "anthologizing intelligence" is discernible in the correspondence between the material and graphiological organization of the page and the intellectual organization of the content, and thereby foregrounds the points where "technologies of book-making" coincide with conceptual structures. ${ }^{8}$ Rawl.poet.31, a commerciallyproduced anthology, is similarly characterized by an "anthologizing intelligence", which makes its presence felt in the mutually reinforcing dialogue between the physical integrity of the book and the sociocultural coherence of its contents.

Bodleian Don.c.54 is a vellum-bound quired folio manuscript book that was probably bought ready-made by Roberts. ${ }^{9}$ Great care went into the making of Robert's anthology and into shaping the material copied into its pages. This is not only a feature of its content, of the groupings of verse, but is also evident in the practices of handcopying, which suggest an understanding of compilation practices as a craft. Very little is known about Roberts. He was born in Shropshire in the marches of Wales and entered Shrewsbury School in 1581 below the rank of a gentleman. Here, he met fellow pupils, George Baugh, Richard Kyffin, John Salsbury, and possibly Francis Crane, who make up one of the scribal communities represented in his anthology. There is a distinct section of Latin verse that begins with a sequence of acrostic poems, spelling “Johans De Sancto Monte' (John Salsbury), "Francisco

\footnotetext{
7 Bland, Guide, 68. On the paper-book, see also Woudhuysen, Sir Philip Sidney, 49-50, and Gibson, "Casting Off Blanks", 210-11.

${ }^{8}$ Seth Lerer, "Medieval Literature and the Idea of the Anthology", PMLA 118 (2003): 125167. J.B. Lethbridge argues for the value of "anthological reading" in "Anthological Reading and Writing in Tudor England", in Barbara Korte, Ralf Schneider and Stefanie Lethbridge (eds) Anthologies of British Poetry: Critical Perspectives from Literary and Cultural Studies (Amsterdam-Atlanta, Ga., 2000), 57-73.

9 The paper is from the same stock produced by Guillaume Journée, a Troyes papermaker, and bears the watermark of the joined arms of France and Navarre, which was made from 1595 to 1603; see Charles Moise Briquet, Les Filigraines: Dictionnaire historique des marques du papier jusqu'en 166o, ed. Allan Stevenson, 4 vols. (Amsterdam, 1968), no. 1855.
} 
Crano' (Francis Crane), and Georgius Baughe (George Baugh), followed by another section of verse, which includes poems by Baugh and verse dialogues between Baugh and Roberts (ff. 12v-16v). These learned dialogues continue in the section of Welsh verse, where these friends are joined by other interlocutors, including kinsmen of Roberts, such as his brother, Hugh (ff. 32r-50v). ${ }^{10}$ Some of this Welsh verse is dated in the 1620 s and 1630s, which indicates that Roberts travelled between London and the marches of Wales for much of his career. It has been suggested that he was a justice on the Welsh circuit, however, there is no evidence for his admission to one of the Inns of Court. ${ }^{11} \mathrm{He}$ may have been the Richard Roberts who matriculated sizar from Jesus College, Cambridge in Easter 1588. A Cambridge connection could explain his interest in the two satires he copied into his book which responded to George Ruggle's Ignoramus performed at Cambridge before James I in 1615 (ff. 23v$24 \mathrm{r}, 26 \mathrm{r}-\mathrm{v}) .{ }^{12}$ If we think about these groupings of verses copied into the manuscript book in Love's terms "as a series of strata, each laid in place by a separate community of readers", then it is possible to discern not only the traces left by the scribal communities to which Roberts was connected, but also how this structural pattern of compilation contributes to the "significant shape" of this anthology in a material sense.

By 1606, Roberts was employed in the secretariat of Ludovic Stuart, second Duke of Lennox; he may have entered his service when Lennox accompanied James to London upon his accession to the English throne. Lennox was a key figure at James's court: he was a Privy Counsellor and first gentleman of James's bedchamber. Membership of Lennox's secretariat gave Roberts privileged access to scribal communities at court and in London. Secretariats were important vectors for scribal transmission. We know through correspondence in Roberts's hand, for example, that he had contact with the secretariat of Robert Cecil, first Earl of Salisbury. It may have been through this channel that Roberts was able to gain access to the rare poem by

\footnotetext{
${ }^{10}$ See the notes written on the end-papers to Bodleian, Don. c. 54, f. 61v.

${ }^{11}$ Robert Krueger writes: "Professor Foster informs me that the Welsh poems in Don identify Roberts as a justice and a wealthy man who spent much time in London", The Poems of Sir John Davies, ed. Krueger (Oxford, 1975), 438. However, I have found no record of the admission of a "Richard Roberts" or "Richard Proberts" to either the Middle or Inner Temples, or Gray's or Lincoln's Inn in the period from 1588 to 1606.

12 Alumni Cantabrigienses, compiled by John Venn and J. A. Venn, 2 Parts, 10 vols (Cambridge, 1922-54), I.iii.466.
} 
Cecil, composed in 1602, "From a seruant of Diana, as faithfull as the best' (f. $7 \mathrm{v}$ ). It is copied under another rare verse, "Of the last Queene by the Earle of Clanricard", ("My loue doth flye with winges of feare"), which again dates from around 1602. Richard Burke, fourth Earl of Clanricarde, was raised in the household of Robert Devereux, second Earl of Essex. Katherine Duncan-Jones has suggested that Roberts's unusual access to "such 'secrett' Elizabethan poems" indicates an Essex connection. ${ }^{13}$ It is possible that this connection was made through Lennox's secretariat which gave Richards access to court circles.

One of the main "strata" or groupings of verse provides evidence for Roberts's access to the scribal networks in London that constellated around the court, Inns of Court, and parliament. There are sequences of verse which testify to Roberts's familiarity with a scribal community of lawyers and self-styled wits, presided over by John Hoskins and Richard Martin, many of whom were active in James's early parliaments and who frequented the Mitre and Mermaid taverns. Members of secretariats also patronized these taverns in this period. ${ }^{14}$ Roberts copies into his book the 1610 petition of the House of Commons against impositions, which he follows with a copy of the "Convivium Philosophicum", a Latin poem said to be occasioned by a feast at the Mitre in late 1611 in mock-honor of Thomas Coryate (ff. 20v-22r). Guests included John Donne and those wits who had been vocal in their opposition to impositions in the Commons: Christopher Brooke, Sir Robert Phelips, John Hoskins, and Richard Martin. Roberts's interest in this scribal community is similarly suggested by the Donne poems he chooses to copy, which consist entirely of verse that Donne addressed to his close friends from the Inns: Sir Henry Wotton ("Heere is more newes then virtue"), Thomas Woodward ("All haile sweet Poet"), and Brooke (“A Calme”) (ff. 8r-9v).

\footnotetext{
13 See the letter from Roberts to the "Gentlemen" in Salisbury's secretariat dated 20 September, 1606, Hatfield House Library, CP 192/127. A photocopy of this letter is on the back pastedown of Bodleian Don.c.54. Katherine Duncan-Jones, “Preserved Dainties': Late Elizabethan Poems by Sir Robert Cecil and the Earl of Clanricarde", Bodleian Library Record 14.2 (1992): 136-144.

${ }^{14}$ HMC, Marquess of Downshire, Papers of William Trumbull the Elder, 1605-1618, II.1823; Michelle O'Callaghan, The English Wits: Literature and Sociability in Early Modern England (Cambridge, 2007), 71-2.
} 
Duncan-Jones and Arthur Marotti have discussed in some detail the political material that Roberts copied into his anthology, particularly the collection of verse libels. For example, Roberts collects a substantial amount of pro-Essex material, including verse libels against Essex's perceived enemies and rivals, such as Sir Walter Ralegh, and those magistrates who took part in his trial: Sir Edward Coke and Henry Brooke, eleventh Lord Cobham, also an ally of Ralegh (ff. 6v-7r, 17r-20r). ${ }^{15}$ Much of this material can be found in other miscellanies and was widely copied. Yet, one of the distinctive features of Roberts's practices of compilation is how often this material is assembled into groupings. This practice suggests that one of the principles for selecting and organizing material for copying in the anthology is occasion, in that verse is chosen because of its relationship to an event, individual or group. Andrew Gordon has coined the term "copycopia” to describe such units of copying which have in common "a specific person or an event" or "share a connection to a particular historical moment”. Such groupings of texts by historical occasion encourage a particular set of interpretive practices which invite readers to read intertextually and contextually. One effect of copycopia is that even loosely related texts may gain added significance through their physical proximity to other texts within the grouping, since this placement encourages their interpretation in relation to the grouping as a whole. ${ }^{16}$ Two pages in Roberts's anthology, for example, are devoted to material relating to the trial in 1616 of Robert Carr, Earl of Somerset, and his wife Frances (née Howard) for the murder of Sir Thomas Overbury. ${ }^{17}$ This section of copying begins with two letters claiming to be written by Frances Howard, prior to her divorce from Robert Devereux, third Earl of Essex (son of the second Earl, executed by Elizabeth I in 1601). The first is addressed to Dr Simon Forman, the second to Ann Turner, in her role as Carr and Howard's go-between (ff. 28r-28v). Copied on the verso are a short prose account of the trials and a list of the commissioners involved (f. 28v). Equally significant are those points in the anthology where material form and intellectual structure coincide. The popular verse libels on the marriage of Carr and Howard are gathered together and copied across an

15 Duncan-Jones, “"Preserved Dainties”", 136-144; Arthur F. Marotti, Manuscript, Print and the English Renaissance Lyric (Ithaca, N.Y., 1995), 36-7, 93-8.

16 Andrew Gordon, "Copycopia, or the Place of Copied Correspondence in Manuscript Culture: A Case Study”, in Material Readings, ed. Daybell and Hinds, 65-8.

${ }_{17}$ As with the Essex material, material relating to the Carr-Howard scandal was also much copied; see Williams's discussion of Victoria and Albert MS Dyce 44 in this collection. 
opening (ff. 22v-23r), thereby foregrounding the interrelationship between material form - the opening - and content.

Roberts's anthology is notable precisely because of the way in which such intellectual structures coincide with codicological features. This means that the anthology is marked by a degree of formal organization which, in turn, argues strongly for a sense of conscious design at work in its compilation. It seems that Roberts did not buy the book pre-ruled, since the ruled lines across an opening leave the gutter unmarked. Instead Roberts carefully ruled the pages throughout, apart from the preliminary and end blank leaves, before texts were copied into the book. The leaves have been folded in half vertically, and, in pencil, two lines have been ruled vertically and five horizontally. With the central crease, which is also sometimes ruled, the page consists of twenty squares, and these are used to organize the copying on the vast majority of pages. This is particularly the case with poetry in double columns; prose tends to be copied leaving the left column as a margin, and across the remaining columns. Roberts seems to have begun the anthology with a plan to produce two distinct sections, and so divided the paper-book roughly in half by casting off blank pages. The first section is reserved for English-Latin verse, and the second consists of Welsh-language poems, beginning with the heading "Welch Verses" in the left margin (f. 32r). These structural divisions produced by casting off blanks are intended to leave space for further copying within sections, suggesting that planning went into its organization from its inception. ${ }^{18}$

Roberts copies much of the material into his anthology in a fair hand, alternating between a highly skilled secretary and an italic hand, and also using red ink for highlighting. There is an art to Roberts's practice of handcopying. While Roberts may not have been a professional scribe, handcopying was part of his profession as a secretary, and presumably an activity that he viewed as a craft and was valued by others. Handcopying was a skill that was honed in the early modern educational system where it acquired an "elevated connection to humanist values and high-level service" ${ }^{19}$ Other amateur compilers also possessed a high level of skill in

${ }^{18}$ See Gibson on casting off blanks and the structuring of paper-books, "Casting Off Blanks", 208-11.

19 North, "Amateur Compilers", 86, 92. On secretaries as professional copyists who made their living by the pen, see Woudhuysen, Sir Philip Sidney, 66-87. 
penmanship. For example, sections within John Ramsey's commonplace book (Bodleian MS. Douce 28) testify to this gentleman's investment in the arts of handcopying and were probably "copied as exercises in penmanship", as Edward Doughtie has suggested. ${ }^{20}$ Ramsey was clearly interested in the arts of calligraphy. He copies into his book Edward Beacon's "The arte of Brachigraphie", an account of shorthand (ff. 125r-25v), and may have been taught by Peter Bales, a highly-regarded writing master, who ran a school in London, near the Old Bailey. ${ }^{21}$ Roberts' skills in penmanship, by comparison, were not only a marker of gentlemanly status, but also prized within his profession and how he made his living, and he advertises these professional skills by putting them on display as a craft that has involved skill, labor and time. ${ }^{22}$

Roberts's and Ramsay's methods of compilation demonstrate an acculturation to the practices of making books both within a manuscript and print trade. There is evidence that Ramsey adopts typographic features from printed books alongside utilizing the skills of handcopying. This interplay between manuscript and print is particularly evident in his copying of Francis Sabie's The Fisher-mans Tale and Flora's Fortune: The second part and finishing of the Fisher-mans Tale, first printed by Richard Jones in 1595. Ramsey tries to replicate in his own title some of the typographic features of the printed title-pages. For Flora's Fortune, he attempts a recreation of the title-page, alternating between scripts to mimic the different fonts (f. 161v). When Jones printed Sabie's text, he added a decorative border down the outside of each page. Ramsey produces a version of this border in the series of decorative curlicues at the end of each line of text on the first pages (ff. 128r, 161v). Yet these curlicues are also Ramsey's own calligraphic decorative features that belong as much, if not more, to a manuscript as a print tradition. Roberts's copying and design of a popular verse libel on Carr and Howard ("There was an old lad rode on an old padde") is similarly illustrative of this ambidextrous use of conventions of manuscript and print. It is given a title that identifies it with a tradition of printed broadside ballads - "A proper new ballad to the tune of whap do me no harme good

${ }^{20}$ Edward Doughtie, “John Ramsey's Manuscript as a Personal and Family Document”, in New Ways of Looking at Old Texts, ed. W. Speed-Hill (Binghamton, N.Y., 1993), 281-88 (285).

${ }^{21}$ Woudhuysen, Sir Philip Sidney, 168, 32-3. For Bales, see also Guillaume Coaten and Fred Schurink, in this volume (p. ???).

${ }^{22}$ North, "Amateur Compilers", 86. 
man or the cleane contrary way" - and a jesting imprimatur: "Imprinted in Poules church yard at the signe of the yellow Band and Cuffes by Adam Arsincke for Robert Roseare, and are to be sould at the Andromeda Liberata in Turnbull streete" (f. 24r).23 Given that both the title and the mock imprimatur only appear in this manuscript, it is likely they were composed by Roberts, and reveal a sophisticated awareness of how the distinct bibliographic features of print can be used for parodic affect within a scribal format.

The crafted nature of Roberts's anthology is on show in the planning of groupings of verse and the design of the mise-en-page. This is evident in the copying of Overbury's "A Wife" (ff. 4r-5r), which is transcribed in double columns using the underlying ruled grid of the page as a guide. Roberts alternates red and black ink for each stanza, a feature which appears to be as much for ornament as for the ease of distinguishing stanzas. Red ink is frequently used both decoratively and to highlight names or sections of poems, particularly in the case of stanzas within double-column poems, and it is also sometimes used to divide the page, in the form of two central vertical double lines, when poems are copied in double columns, notable in the section of Welsh verses (ff. 4r-17r, 32r-50v). The arts of compilation are similarly evident in Roberts's design of an opening devoted to libels on Edward Coke, alias "Cocus", and his wife (f. 6v-7r). Here, material form (the opening), content, and the arts of penmanship coincide. The significance of the content is foregrounded through the use of a detailed explanatory headnote copied in red ink: "A libel vpon $\mathrm{M}^{\mathrm{r}}$ Edward Cooke, then Attorney general and sithence Cheife Iustice of the Common pleas vpon some disagreement. betweene him \& his wife being widow to Sir William Hatton knight. and daughter to the now Earle of EXETER then Sir Thomas Cecill" (f. $6 v)$. The copying of these Coke verse libels and satires is organized into double columns, with red ink used both for decorative effect and to highlight content, such as names and passages. Similar design features are also noticeable in a section of poems headed "By Mr JOHN DVNNE" (f. 8r). Once again red ink is used to highlight passages, however, in the case of "A Calme", red ink seems to be used for purely decorative effect, based on the layout of the page rather than content (f. 9v). ${ }^{24}$ This

\footnotetext{
23 Marotti, Manuscript, Print, 327.

24 The poem is copied across the two central columns, leaving a column either side as margins, and only the verse lines within the third block of the grid are set out in red ink.
} 
distinctive style of handcopying, identifiable through the use of red ink and the grid pattern, is a design feature that means that there the mise-en-page has a characteristic style, and hence a degree of uniformity.

While I have emphasized planning and stylistic uniformity when discussing the book's compilation, it should also be noted that the chronology of copying material is uneven, given that Roberts copied material into his anthology over a number of years, from around 1602 to the mid-1630s. ${ }^{25}$ There is evidence for discontinuous layers of copying on a page on which there was originally - on the basis of the color of ink, the style of copying, and content - probably only two Latin verses, generously set out, and part of a longer section of Latin verse (f. 11r). At some later point, Roberts went back to these pages and added notes and further poems in the available space, which are all copied in a noticeably lighter ink and in a looser secretary hand. Later additions include a note added to the title of the Coryate verse, "per scolasticum westmonaster", and a poem "vpon the vnion: by Ben Jonson", copied across the second ruled column on the page, beside the Latin acrostic poem, which spells "Richardo Roberts Salutem". At the bottom of the page two poems are copied: "Even such is tyme, which takes on trust", and "What is our life? it is a play of passion", with the note "said to be done by Sir Walter: Rawleighe" in the margin beside the first. The copyist, presumably Roberts, has had to squeeze these poems into the available space at the bottom of the page. Hence, in the case of the first poem, two verse lines comprise one written line, thus leaving enough space for the second poem. In general, the mise-en-page tends to be more disorderly at the beginning and end of the volume. For example, poems, notes, and a letter said to be written by Susan Caesar to her sister Lady Lake have been copied on the pastedown and leaves at the front of the book at different times, probably after the main body of the volume (ff. 1v-2r). The unevenness of these sections foregrounds the comparative regularity of the copying across the rest of the collection, which, in turn, means there is a core to the paper-book identifiable by its relatively uniform mise-en-page.

The importance of studying the history of copying within a manuscript is foregrounded in the case of Roberts's use of marginal notes. The purpose of these

${ }^{25}$ See Gibson on the significance of diachronic processes of copying in "Synchrony and Process", 85-100. 
marginal notes is closely related to that of his headnotes, which are often very detailed and characteristically record particulars of the events and the individuals involved. In the case of the letters attributed to France Howard, marginal notes and headnotes work in tandem. The marginal notes identify individuals referred to in the letters, while the first letter is prefaced with a detailed explanatory headnote: "The Countess of Essex beinge daughter to the earle of Suffolke grewe to dislike with her husband fell in loue with Sir Robert Carr Viscount Rochester and afterwards earle of Somersett: and for the accomplishinge of her lasciuious desire she dealt with an impostor called Doctor Forman a very brave, who as seemeth promised to worke wonders, and to him she writeth this gracious lettere" (f. 28r). Through such careful textual glossing, the copyist-compiler becomes an editor. ${ }^{26}$ Writing of the printed book, Evelyn Tribble has argued that the glossed page is a site where new relationships are formed between author and reader. ${ }^{27} \mathrm{~A}$ comparable point can be made about the uses of glosses in manuscripts, particularly those which display a degree of planning. Against his copy of the "Convivium Philosophicum", Roberts added the names of those attending in the margin against their Latin pseudonyms: "Christopher Brooke", "John Dun”, "Lionell Cranfield”, "Arthur Ingram”, and so on (ff. 21r-22r). These notes may have been intended as a personal aide-memoire. Yet, by displaying knowledge which places the copyist-editor in a privileged position in relation to a reader, they also assume the existence of these other, future readers. At a later point, probably over a period of time from the 1620 s to 1630 s, Roberts went back over his compilation to add further explanatory, editorial notes to the texts on some pages. So, for example, after the attribution of the "Convivium Philosophicum" to Hoskins, Roberts provided an update on his career, recording Hoskins's promotion to sergeant-at-law in 1624 (f. 22r). Similarly, between Donne's verse epistles to Wotton and Woodward, Roberts adds the note "By $\mathrm{M}^{\mathrm{r}}$ John Dvn once Secretary to the Lord keeper Egerton, disgraced by him for marrying with his wives neece: since proceeded doctor of divinitie one of the kings Chaplens: and now this paste Moneth of Aprile 1624 Deane of Powles" (f. 8r). Marotti says of this note that "it replaces the immediate sociopolitical context of the verse letter with that of the poet's extended public life'. ${ }^{28}$ These editorial notes seek to establish the primary

${ }^{26}$ On the compiler as editor, compare Jessica Edmondes in this volume (p. ??).

27 Evelyn Tribble, Margins and Marginality: The Printed Page in Early Modern England (Charlottesville, 1993), 57.

${ }^{28}$ Marotti, Manuscript, Print, 150. 
context for reading the verse, and ask that the reader interpret the poem and its subject historically. At one level, these notes may function as a personal mnemonic device, a reminder to Roberts as the book's primary reader. Yet, these notes also do more work than this suggests. They act as a form of record-keeping which turns these often occasional poems into historical texts, and attempts to stabilize their interpretation for acts of reading not just in the present, but also in the future.

The high level of skill evident in Roberts's compilation of his anthology, in large part, derives from the fact that he worked within a secretariat, and hence within a profession in which the arts of handcopying were prized. That said, his anthology differs from a professionally-produced manuscript. Organized structures of copying and distinct elements of deliberate design co-exist alongside less crafted and more haphazard features. There was another type of paper-book available in the period in which the "anthologizing intelligence" has a commercial aspect. Alongside pre-bound blank paper-books, individuals could also buy or commission manuscript books of poetry produced by professional scribes. In these cases, the uniformity of the miseen-page is even more marked and the chronology of copying often invisible. ${ }^{29}$ The aim is to give the appearance of a unified whole, which, in turn, reinforces the status of the manuscript book as an anthology. Bodleian MS Rawl.poet.31 is an example of a commercially produced manuscript anthology. It is the work of a professional scribe, known as the "Feathery scribe" from his distinctive hand. While this anthology exhibits a greater degree of uniformity in its copying than Roberts' manuscript book, it nonetheless shares features of design and content, the latter deriving from the social character of the verse that it collects, which, in turn, contributes to its "significant shape". "Feathery scribe" worked in a London scriptorium from the late 1620 s to around 1641, coinciding with Charles I's Personal Rule. $3^{\circ}$ Rawl.poet.31 is a carefully crafted folio paper-book, designed for a library rather than the pocket. It is generously set out: there are wide margins, copying is spacious, and, on the whole, the mise-en-page is planned with generosity. There is plenty of material evidence of order and design to indicate that the collection was set out with care and with a sense of its structure as a book. The presence of catchwords, a device used by both scribes

\footnotetext{
${ }^{29}$ North, "Amateur Compilers", 95-6.

30 Peter Beal, In Praise of Scribes: Manuscripts and their Makers in the Seventeenth Century (Oxford, 1998), 58-108.
} 
and printers to ensure that leaves are ordered sequentially for gathering and binding, would indicate that the contents were copied on loose leaves in quires, and in preparation for binding. Design is also evident in the book's aesthetics, which, in turn, are very much the Feathery scribe's trademark. Titles, in an elaborate secretary and italic hand, are centered; decorative lines mark the end of poems; and punctuation is frequently used for stylistic effect rather than function. A characteristic feature is the use of the colon after the first word of a title or verse, to set the word off in a similar fashion to the use of decorative initials.

These design elements appear to be a feature of professionally compiled manuscript anthologies more generally. Hence, Rawlinson is comparable with a manuscript anthology once owned by Chaloner Chute and compiled in the 1630 s by a professional scribe whose main work appears to have been copying plays. ${ }^{31}$ It too is a carefully crafted manuscript book, and, like Rawl.poet.31, bound in limp vellum. Margins are ruled throughout and titles of poems inscribed in a simple cartouche, as are the names of authors when given; these cartouches are all placed underneath the verse and aligned to the right. At the end of the collection is "An Index of ye Pieces in this Booke” (f. 97r), set out in a double column organized alphabetically by first line, with the corresponding folio number aligned in separate ruled column. The material stylistic features of these paper-books mark them out as collections constructed "for the purposes of compiling a book", and as a product of conscious design rather than happenstance. It is a question whether this design principle carries through from physical form to content, whether the poems collected in their pages are copied in such a way as to play "a particular and considered role in the sequence of contents" and whether there is a schema or set of principles determining their selection. ${ }^{22}$ The Chute manuscript book is an anthology of poetry fashionable in manuscript compilations of the 1630 s and 1640s. It includes poems by Ben Jonson, Donne, and Francis Beaumont, as well as verse by a younger generation of poets: Robert Herrick,

\footnotetext{
${ }^{31}$ Arthur F. Marotti, "Chaloner Chute's Poetical Anthology (British Library, Additional MS 33998) as a Cosmopolitan Collection”, English Manuscript Studies, 1100-1700, 16 (2012): 112-40; Eckhardt, Manuscript Verse Collectors, 17-18. There is a note in italic hand, possibly inscribed by a young woman in the Chute family, on the pastedown and translated below, suggesting a schoolgirl exercise: "Mon cousin Chute ma donez le liure hors de l'etude de son pere a la Vine Hampshire"; "My cousin chute gaue me this book out of his fathers study at the vine Hampshire".

${ }^{32}$ Boffey, Manuscripts, 9, 11.
} 
James Shirley, William Davenant, Zouch Townley, Henry King, Thomas Carew, Joseph Mayne, and Thomas Randolph. Marotti has argued that this anthology, through the verse it consciously collects, "define[s] a developing Cavalier sensibility, celebrating erotic refinement and gentlemanly swagger". The type of poetry and its authors, as well as the inclusion of rare verse by Herrick, Carew and Randolph in the anthology, locate the volume within an elite London milieu, which constellated around the Caroline court and the Inns of Court.33 A schema is also discernible in the physical organization of poems according to genre within the collection. Hence, there is a section of verse epistles, with individual poems often given a title beginning " $\mathrm{A}$ letter" (ff. 8v-11v), and a substantial section of elegies and epitaphs (ff. 31v-42v).

Joshua Eckhardt proposes two hypotheses about the compiler: the first, that it was Chaloner Chute who commissioned "the playhouse scribe to make a fair copy" of verse he had collected; the second possibility, "(although impossible to prove) [is] that this scribe provided or even chose texts for his client". 34 When these questions are addressed to Rawl.poet.31, the hypotheses are similarly intriguing, and just as difficult to prove. Both the Chute manuscript and Rawl.poet.31 were produced around the same time, from the mid to late 1630s.35 When their contents are compared, however, Rawl.poet.31 emerges as a rather idiosyncratic compilation. Whereas the Chute anthology collects verses from poets writing under James and Charles, Rawl.poet.31 collects poetry exclusively from the 1590 s to around 1610. While the two anthologies both include the poetry of Jonson, Donne and Beaumont, Rawl.poet.31 is highly unusual for a verse compilation produced in the mid to late 1630 s in that it does not include any verse from a younger, Caroline generation of poets. Although this feature lends the collection a stylistic and social coherence, it also produces in an anthology that is retrospective rather than contemporary. The question of who compiled this anthology and the type of texts to which the collector had access is therefore particularly intriguing.

\footnotetext{
33 Marotti, "Chaloner Chute's Poetical Anthology", 113-118.

34 Eckhardt, Manuscript Verse Collectors, 17-18.

35 The Chute manuscript could have been compiled as late as the 1640 . The paper stock used for Rawlinson bears the grape watermark, which Bland dates to 1633-1634 (Guide, 33); however, Feathery was still using this paper stock as late as 1638 (Beal, In Praise of Scribes, 215-16).
} 
One possibility is that the anthology was put together by the Feathery scribe from manuscripts in his possession. Feathery worked for Ralph Starkey, the antiquarian, who had obtained the papers of William Davison, Elizabeth I's former Secretary of State, and his son, Francis Davison, the anthologist. In Starkey's possession was Francis Davisons's list of "Manuscripts to gett”, which included "POEMS of all sorts", "Diuine" and "Humane"; "Psalmes by ye Countes of Pembroke" (on the proviso that "they shall Not bee printed”); "Psalmes by Josuah Siluester", “Sir John Harrington", and "Joseph Hall”; Donne’s "Satyres, Elegies, Epigrams"; "Poems by Ben. Johnson"; and "Henry Constables 63 Sonnets". ${ }^{36}$ Along with his printed verse anthology, $A$ Poetical Rhapsody, this list attests to Davison's systematic collection of poetry from the last decade of Elizabeth's reign until his death around 1611. The Davison papers, however, were seized from Starkey by order of the Privy Council in 1619, apparently before Feathery began working for Starkey in the 1620s.37 There is a very small possibility that Starkey may have been able to retain manuscripts of verse once in Davison's possession, which then made their way to Feathery. One reason for entertaining this possibility are the signs that Rawl.poet.31 was once a sample book compiled by Feathery both as an example of his work (hence as Beal notes, Rawl.poet.31 is "Feathery in full showcase mode") and as a collection from which clients could choose poems to create their own anthologies. ${ }^{8}$ This would, in turn, suggest that Feathery made use of manuscripts already in his possession. Carets $\left({ }^{\wedge}\right)$ are placed in the margin alongside seven titles in the book, possibly marking these poems for selection: "I and my Love ffor kysses playd" (f. 2v), "In elder tymes the Auncyent Custome was" (ff. 3r-3v), "The Godlye Maid" (f. 3v), "What a woeman is" (ff. 3v-4r), "Is't ffor a grace, or ist, ffor some dislike" (f. 4r), "Come sweete (Celia) lett us prove" (f. $7 \mathrm{r}$ ), "Kisse mee sweete, the warye lover" (ff. $7 \mathrm{r}-7 \mathrm{v}$ ).

Beal, however, has argued that Rawl.poet.31 "must surely have been a commissioned anthology".39 If so, then this individual must have had access to a poetry collection that Rawlinson shares with another manuscript, BL MS Harley 4064, compiled around 1610-12. These two manuscripts not only have in common a substantial

\footnotetext{
${ }^{36}$ BL Harley MS 298, f. 159v.

37 Beal, In Praise of Scribes, 91-2. On Feathery, see also Woudhuysen, Sir Philip Sidney, 1859.

${ }_{38}$ Beal, In Praise of Scribes, 104; on sample or specimen books, see Woudhuysen, Sir Philip Sidney, 181.

39 Beal, In Praise of Scribes, 104.
} 
number of poems, but they are copied in often identical sequences. $4^{\circ}$ The fact that the order of the poems in both compilations is so very close suggests that the underlying papers they share were already organized into distinct groups of poems. In other words, this was not simply a set of loose randomly assembled papers, but already some type of collection, probably including small booklets of verse. There are sequences in the two manuscripts that group poems by author, however, these selections are more pronounced in Rawl.poet.31. So, for example, there is a group of poems, many of which were printed in Sir John Harington's Epigrams (1618; 1633), and a popular misogynist verse, "What a woeman is", possibly also associated with Harington, that appears in the same order in both manuscripts (Harl. 4064, ff. 233r34r; Rawl.poet.31, ff. 3r-5r). Rawlinson, however, includes another poem attributed to Harington ("Is't ffor a grace", f. 4r), and another popular misogynist verse ("The Godlye Mayde", f. 3v), not in the Harley sequence. This suggests that a further process of selection was at work and, here, it has the effect of producing a comparatively coherent generic grouping. A similar process can be seen in relation to a group of five Jonson verses in Rawl.poet.31 (ff. 7r-9r). Rawl.poet.31 shares only the two odes ("Where doost thou carelesse lye", and "Yff Men, and tymes were nowe") with Harley 4064, and then includes a further three songs from Volpone and Epicoene, not in Harley, to produce a distinct grouping of Jonson verses. Rawl.poet.31 also includes a group of Sir Edward Herbert's poems, not present in Harley 4064, which possibly came to the compiler in the form of a little booklet. The sequence is headed with the attribution "Off Sir Edward: harbert". The mode of copying these Herbert poems, and resulting visual appearance, strongly indicates that they were quite consciously designed to be read as a distinct sequence: each poem - "Idea", "To Hir fface", "To Hir Bodye", "To Hir Mynde" - is separated by a curlicue, and the group as a whole is divided from the rest of the collection by a decorative line (ff. 14r-16r). These poems are rare: "To Her Body" is only found in this manuscript, and the others survive in only one other manuscript, owned by Meriall Tracy (c. 1620-33).41

\footnotetext{
$4^{40}$ Bland, Guide, 101.

${ }^{41}$ Herbert had a collection of his poems copied by a scribe, probably in his employ, in the 1630s; see Woudhuysen, Sir Philip Sidney, 105.
} 
The stylistic and social coherence of Rawl.poet.31 is comparable to Chute's anthology, although the milieu it records belongs to an earlier period. The type of poetry and the authors and addressees of the verse that Rawlinson collects invokes a social world and defines a milieu that was active at court and in London from the late 1590 s to the 1610s. Sociality is one of the key intellectual structures that organizes the content and provides the anthology with its "significant shape". A characteristic pattern of compilation places poets in relation to each another, and is noticeable in the interlaced sets of poems by Donne, Jonson, Herbert, Sir John Roe, William Herbert, third Earl of Pembroke, Sir Benjamin Rudyerd, and Beaumont that structure the collection. Social poems dominate the second half of the compilation. Two verse epistles - "The stat[e], and Mens affayeres" (f. 24r-4v) and "Yff greate Men wronge mee" (ff. 25r-5v) - subsequently attributed to Roe, are addressed to Jonson in the headnotes and prefaced by Jonson's verse epistle "Censure not sharplye then" (f. 23v), titled "An Epistle to a Friend" in The Underwood (1640), although here it is unattributed and untitled. ${ }^{42}$ Four poems that sometimes circulated separately or in pairs are here organized into a verse dialogue (ff. 3or-33v), their speakers identified by the initials "P" and "R": Pembroke and Rudyerd. There are two verse epistles addressed "To the Countesse of Rutland", Sir Philip Sidney's daughter, Elizabeth Manners: Jonson's "Whilst that ffor which, all virtue, now is sould" (ff. 18v-2or) and Beaumont's "Maddam: Soe maye my verses pleasinge bee" (ff. 37v-9r). By far the largest group of poems consists of verses addressed to, commissioned by, or closely associated with Lucy Russell, Countess of Bedford. Her presence lies behind elegies and epitaphs for Lady Bridget Markham and Cecilia Bulstrode, her close friends, kinswomen, and fellow members of Queen Anne's Bedchamber, who died within months of each other in 1609. George Garrard, Sir John Roe's cousin and Donne's close friend, acting as a proxy for Bedford, commissioned these elegies and epitaphs from his poet-friends, some of whom were also her clients.43 Rawl.poet.31 thus includes elegies and epitaphs on Markham and Bulstrode penned by Jonson (ff. 3r-6v), Sir Edward Herbert (ff. 36v-7r), Donne (ff. 45r-6v), and Bedford's own elegy for Bulstrode, here entitled "Elegie on the Ladye

\footnotetext{
${ }^{42}$ See my discussion of the companionable intertextuality of these verse epistles as they are copied in Raw.poet.31 in "Those Lyrick Feasts made at the Sun, the Dog, the Triple Tunne': Going Clubbing with Ben Jonson", Lords of Wine and Oile: Community and Conviviality in the Poetry of Robert Herrick, ed. Ruth Connolly and Thomas Cain (Oxford, 2011), 83-105 (84-8).

43 R.C. Bald, John Donne: A Life (Oxford, 1970), 177-78.
} 
Marckham, by L: C: B:" (f. 39ar-9av). This section of the anthology, in particular, is structured by a shared sociocultural idiom that is identifiable with the milieu that gathered around Bedford in the early years of James's reign.

Like other anthologies of this period, much of the verse in the manuscript is unattributed, which suggests that its aim was not to canonize the works of a particular set of authors; rather authority is invested in the milieu defined by the collection. The only authors named in headnotes are Sir John Harington and Sir Edward Herbert: Jonson is named on two occasions, but as the addressee of verse epistles. Pembroke, Rudyerd, and Bedford are identified by their initials. That said, the names of the addressees of verse are recorded throughout the compilation in a manner which structures the social landscape of the manuscript book: Queen Elizabeth (f. 3r); the Countess of Rutland (ff. 18v, 37v); Lucy, Countess of Bedford (ff. 20v, 39br, 46v); Cecilia Bulstrode (ff. 26r, 45r); Lady Markham (ff. 3or, 39ar); and Sir Robert Wroth (f. 34r). This interplay of anonymity, naming, and initials, as Marcy North has said of the "mix of naming and anonymity" in the Arundel-Harington manuscript, "works to focus attention on coterie relationships and identities rather than authorship", and gives the impression that the anthology is the product of an "intimate world of private text transmission where readers and authors are reasonably familiar with one another". 44 In conjunction with the sociality of the verse collected, the effect of these markers of status and social intimacy is to bestow on the compilation a coterie identity.

To understand why only certain authors and addressees of verses were included in the Dalhousie manuscript, Ernest Sullivan used the metaphor of a private party to explain its very restricted "guest list", which is confined to those closely related to the family of the earls of Essex through ties of kinship, friendship and clientage. 45 The "guest list" of Rawl.poet.31 is similarly restricted, in this case, to those connected through kinship, clientage and friendship to the Countess of Bedford. Aside from three poems, attributed to Ralegh, Thomas Campion, and Sir Robert Ayton, all other

44 Marcy North, The Anonymous Renaissance: Cultures of Discretion in Tudor-Stuart England (Chicago, Ill., 2003), 167, 177.

45 Ernest Sullivan, "The Renaissance Manuscript Verse Miscellany: Private Party, Private Text", in New Ways of Looking at Old Texts, ed. W. Speed Hill (Binghampton, N.Y., 1993), 289-97 (292-7). 
known authors of the verse collected in the volume can be linked to Bedford: Harington was her kinsman; Pembroke, her close friend; Jonson and Donne were her clients; Roe was linked to her household via Bulstrode and Jonson; and, as the elegies for her kinswomen indicate, Sir Edward Herbert and Beaumont similarly cultivated a connection with her. If Bedford was at the epicenter of this network, then Jonson and Donne can be seen as nodal points strengthening the ties of other poets, such as Roe and Wotton, with Bedford. The anthology, at least in part, therefore appears to record a scribal network constellated around the Countess and active from around 1601, at the end of Elizabeth's reign, to around 1610.46

The social cohesiveness of Rawl.poet.31 results from practices of selection. Yet, does this cohesiveness result from a deliberate strategy on the part of the collector or from the type of verse to which he or she had access? The differences between Harley 4064 and Rawl.poet.31 suggest that some type of editorial decisions were made when compiling the collection. The question remains: why was such a volume commissioned in the mid to late 163 os when the verse it collects was well over two decades old? The clue may lie in the coterie identity that the collection both fashions and crucially preserves. And here, Roberts and the compiler of Rawlinson share an understanding of the purpose of the manuscript book that goes beyond its immediate social uses. Just as the framing material Roberts added to his manuscript turns occasional verse into historical texts, recording the milieu in which verse circulated for posterity, so too Rawl.poet.31 preserves these social texts and secures their coterie identity for acts of reading not just in the present, but also in the future. Rawl.poet.31 can be understood as constituting a publication event that captures not only texts at a certain point in their transmission history, but also the coterie identity that they define, and imparts to both a momentary stability and coherence within the format of the professionally-produced paper-book. It is therefore makes available for consumption, by a reader or a readership, not an anthology of contemporary poetry, but a retrospective and, in some sense, nostalgic collection that captures a coterie culture that is now past.

${ }^{46}$ Melanie Faith notes Bedford's involvement in a court coterie as early as 1601, "Correcting the Date of the 'Conceited Newes", Notes and Queries 53 (2006): 505-8. 
While the compilation of manuscripts was an often uneven process, nonetheless, as the manuscript books examined in this essay demonstrate, conceptual and material structures often coincide to provide a compilation with a "significant shape". Analyzing particular instances of this phenomenon in Roberts's anthology and Rawl.poet.31 tells us something about shared and different practices of compilation at work in the production of commercial and personal paper-books. In the case of Roberts, it also reminds us that although, as North points out, there was not an organized trade involved in the compilation of manuscript verse anthologies,47 nonetheless, the high level of skill and an awareness of design evident in those manuscripts, such as Roberts', indicates that some "amateur" compilers understood their practices of compilation as a craft. The early modern paper-book, with its underlying formal structures, insistently draws our attention to these points where the technology of making books intersects with acts of interpretation.

47 North, “Amateur Compilers", 83. 